\title{
The Visual Image of Teachers: \\ A Ten-Country Perspective
}

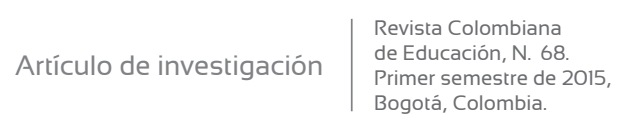

Bogotá, Colombia.

\section{//La imagen del maestro vista desde diez países}

\section{//A imagem do professor vista \\ desde dez países}

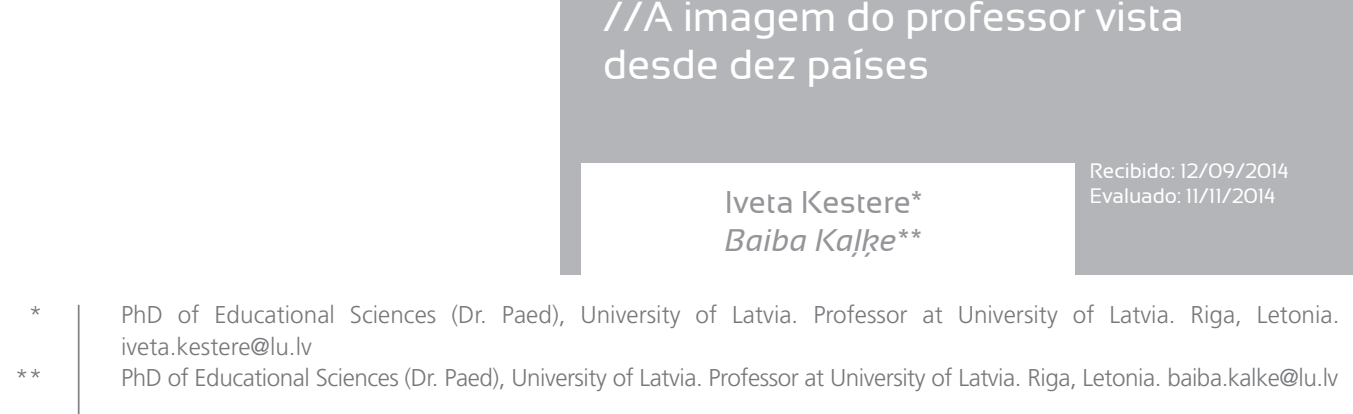

\section{Resumen}

Debido a la interacción social en el proceso de enseñanza-aprendizaje se ha formado una imagen del maestro en la mente de los estudiantes, que posteriormente se reproduce en el espacio público. Entendemos imagen como el fenómeno que se desarrolla en la conciencia humana como resultado de la experiencia social en forma de sistemas de signos. La investigación muestra que la imagen del maestro en el espacio público no siempre es positiva. En consecuencia, el prestigio de la profesión se ve afectado de manera negativa. Para comprender el fenómeno mediante el cual la imagen del maestro se forma en la memoria colectiva de la sociedad, iniciamos una serie de estudios encaminados a establecer el estado de la cuestión. ¿Cuál es la imagen de un maestro típico de acuerdo con los estudiantes en la actualidad? Uno de los estudios se realizó durante el año académico 2011-2012 bajo la supervisión de maestros universitarios en diez países: Bulgaria, Grecia, México, Pakistán, Serbia, Eslovenia, Inglaterra, Sudáfrica, Turquía y Letonia. En el estudio participaron 1053 estudiantes de 15 años. Se analizaron los siguientes componentes que describen la imagen del maestro: sexo, edad, apariencia, rasgos de la comunicación verbal y no verbal. Se analizó la imagen del maestro en el contexto de las características sociales de la profesión y el contexto cultural. También se tuvo en cuenta la edad de los encuestados. El estudio reveló la importancia de la personalidad de los maestros en la vida de los estudiantes. Son modelos a seguir. Este pedido de la sociedad de una persona ideal en la enseñanza puede causar malestar en los maestros reales. Las afirmaciones de los encuestados sobre el maestro como una figura extremadamente importante en la vida de los jóvenes es el principio para aumentar el prestigio de la profesión docente.

\section{Abstract}

Due to the teaching and learning social interaction, an image of teachers is formed within the students' mind, which is later reproduced in the public space. We understand image as a phenomenon taking place in human consciousness as a result of social experience in the form of sign systems. As the research shows, the teacher's image in the public space is not always positive. Consequently, the prestige of the profession is negatively affected. In order to understand the mechanism by which the teacher's image is formed within the collective memory of society, we started a series of studies meant to find out the state of the art. What is the image of a typical teacher according to current students? One of the studies was carried out during the 2011-2012 academic year, under

\section{Palabras clave}

Docente, imagen del maestro, profesión docente, Letonia.

\section{Keywords}

Teacher, teacher's visual image, teacher's profession, Latvia.

\section{Palavras chave}

Docente, imagem do professor, profissão docente, Letônia. 
the supervision of university teachers in ten countries -Bulgaria, Greece, Mexico, Pakistan, Serbia, Slovenia, England, South Africa, Turkey and Latvia-. The participants of the study were 1053 students, aged 15. The following components describing the teacher's visual image were analyzed: gender, age, appearance, verbal and non-verbal communication features. The teacher's visual image was analyzed in the context of social characteristics of the profession and cultural context. The respondents' age was also taken into consideration. The study revealed how important a teacher's personality is in students' life. He/she is a role model. This requirement of society for an ideal person in teaching can create discomfort in real-life teachers. Also, the respondents' statements about teachers as an extremely important figure in youngsters' life serve as a basis for increasing the prestige of the teaching profession.

\section{Resumo}

Devido à interação social no processo de ensino-aprendizagem tem-se formado uma imagem do professor na mente dos estudantes, que posteriormente se reproduz no espaço público. Entendemos imagem como o fenômeno que se desenvolve na consciência humana como resultado da experiência social em forma de sistema de signos. A pesquisa mostra que a imagem do professor no espaço público não sempre é positiva. Em consequência, o prestigio da profissão se vê afetado de forma negativa. Para compreender o fenômeno por meio o qual a imagem do professor se forma na memória coletiva da sociedade, iniciamos uma serie de estudos encaminhados a estabelecer o estado da arte. ¿Qual e a imagem dum professor típico de acordo com os estudantes na atualidade? Um dos estudos realizou-se nos anos acadêmicos 2011-2012, baixo a supervisão de professores universitários em dez países: Bulgária, Grécia, México, Paquistão, Servia, Eslovênia, Inglaterra, Sudáfrica, Turquia e Letônia. No estudo participaram 1053 estudantes de quinze anos. Analisaram-se os seguintes componentes que descrevem a imagem do professor: sexo, idade, aparência, rasgos da comunicação verbal e não verbal. Analisou-se a imagem do professor no contexto das características sociais da profissão e o contexto cultural. Também se teve em conta a idade dos entrevistados. O estudo revelou a importância da personalidade dos professores na vida dos estudantes. São modelos a seguir. Este pedido da sociedade de uma pessoa ideal no ensino pode causar malestar nos professores reais. As afirmações dos entrevistados sobre o professor como uma figura altamente importante na vida dos jovens é o principio pra aumentar o prestigio da profissão docente.

\section{Topicality on Teacher's Image}

Current research on the teacher's image is closely connected to the importance of the teacher as a professional, both in society and in individual life. Society has entrusted teachers (in the classical understanding of this profession) the responsibility to educating the young generation. Therefore, resources, time and space to accomplish this task have been alloted to him/her. How teachers use the provided resources largely depends on their professional competences. Traditionally these are the ones that call politicians', education leaders' and researchers' attention.

However, in teaching the professional quality is closely connected with personality features. Teachers not only provide 
knowledge, but, whether willingly or unwillingly, influence their students' own personality. During the process of mutual interaction -teaching and learning-a teacher's image is formed within the students' mind (Fischer \& Kiefer, 2001, p. 103) which is later reproduced in the public space. We understand image as a reflection on the phenomenon that develops in human consciousness as a result of the previous social experience in the form of sign systems.

While education authorities and politicians argue about the curricula and the teacher's professional competences, the personal relationships taken place at school are preserved within the memory of individuals more vividly than any equation. Unfortunately, a number of studies indicate that this experience is negative rather than positive. According to Weber and Mitchell (1998), widely understandable "code" words are used in the public sphere for describing teachers-gender: female, appearance: ugly (orthopedic shoes, thick glasses, hair tied back in a neat bun); behaviour: unfriendly (p. 1).

Certainly, this "anti-heroine" image poses a question -Why does the society see teachers like that? Where has this stereotyped image "come from"? Probably, the teacher has become a scapegoat for all the emotions experienced at school -fear, aggression, strict discipline, testing, disappointment, and so on. Enzelberger (2001) states that adults often reduce negative and emotional experiences gained at school on the teacher and blame him or her for their failures in their own or their children's life. Negative experiences stay in the memory the longest, and they are very stable because they have caused deep emotional experience while the positive ones often have been self-evident. Therefore, the negative image of teacher is the one that stays in the collective memory. As Ayers (2001, p. 209) says, sometimes this memory is more dogmatic than any political power and more consolidating than any religious group. Thus, negative stereotypes-whether deserved or undeserved-are very difficult to change. Consequently, the prestige of teachers gets affected.

We connect current research on our topic of study directly with the prestige of teachers.

OECD indicators show that two thirds of teachers in the European Union employed in secondary education are 40 and beyond (Education at a Glance, 2012). Thus the question on how to attract young, creative, smart, and active people to teaching is a topical issue in Latvia as it is in many other countries. Certainly, a significant place here should be given to the prestige of the profession in society, which is traditionally determined by factors such as the professional group's social background, training, legal position, salary, and degree of control over the profession (Depaepe, 2000, p. 359). We can definitely add that teacher's image in the collective memory of the society is also 
influenced by other factors. Undoubtedly, if a negative image of the professional is more reproduced in the public sphere than a positive image, it will be affected. In order to understand the mechanism by which a teacher's image is formed in the collective views of society we started a study intended to stablish the state of the art. The research question is: What is the image of a typical teacher from students' perspective?

\section{Research methodology of the teacher's image}

A pioneer study on teacher's image is Margaret Mead's The School in American Culture (1951). Teacher's image in the following decades has been explored using different sources, including some historical ones.

Teacher's image from a historical perspective has been the focus of several international scientific journals and conferences. Textbooks, fiction books, photographs, drawings and cartoons have been used to study teacher's image. The studies by Nóvoa (2000) and Vick (2000) analyzing teacher's image in Europe during the second half of the nineteenth century-where the research methodology is also described-are still widely quoted.

Teacher's current visual image is studied both through interviews and in drawings. It can be said that the work in this field started with the study by Chambers (1983), where students in France, Canada and Australia were asked to draw a typical scientist. Later, images of other professionals, including teachers, were explored using a similar methodology. Such studies nowadays are rather widely spread in the world. For example, Utley \& Showalter (2007) and Smith (2009), carried out studies on the image of specific subject matter teachers, and Hobson (2001) conducted a research on teacher's image for different generations.

The mass media-films, tv shows, advertisements, press, internet resources, and so on-are used to study teachers' visual image in the public sphere. For instance, some American researchers have analyzed teacher's image in the popular television series The Simpsons (Kantor et al., 2001).

Weber and Mitchell published That's funny you don't look like a teacher: Interrogating images and identity in popular culture (1995, reprinted 1998), a remarkable study on the topic. Joseph \& Burnaford (2001), American scientists, also conducted a research on teacher's image. 
Up to this moment, researches had been performed in the American and British culture. Therefore, in order to gain a better understanding on teacher's image in a broader sense it was important to conduct studies in other societies and cultures. Such a study was carried out in the academic year 2011/-2012 under the supervision of university teachers in ten countries -Bulgary, Greece, Mexico, Pakistan, Serbia, Slovenia, England, South Africa, Turkey, and Latvia. Accidence and the researchers' contacts that correspond to the cluster sample (Cohen et al., 2007) played an important role in the selection of the countries. The results of the study were published in a book edited by Kestere, Wolhuter and Lozano (2012).

The above mentioned research on teacher's image, as well as the study on teacher's image from Latvian students' view (Kestere \& Kalke, 2011) served as the methodological basis of the study. The following remarkable components building up teacher's visual image were identified based upon these publications: gender, age, appearance (i.e. clothing, jewelry and accessories, hairdo, and figure), verbal communication features (voice, tone) and non-verbal communication features (mimicry, body language).

Each country in the study was represented by 89 to 140 fifteenyear-old students. The total number of respondents was 1053. This age group was chosen because in many countries students at this age attend general comprehensive schools and they have not yet enrolled in different educational institutions matching their professional interests. Thus, this audience as a whole is homogeneous and comparable from one country to other. Students this age have developed abstract thinking; their experience in the relation with teachers is no longer influenced by revering and idealization of the authority, or by the explicit riot towards the adult world that are characteristic to younger students (Rutka, 2012). Thus, the respondents in their description of teacher's image are rather objective.

The respondents' group in each country was gathered so that it was a representative sample of societyboys and girls, rural and urban inhabitants, from different ethnic and origin backgrounds. Based upon the studies by Chambers (1983), and Weber and Mitchell (1998), one open question was used as the data collection method. This question could be answered in writing and/or drawing. Each respondent received a piece of paper with the question "What does a typical teacher look like?" written in his or her native language, or a language understandable to him/her. Respondents were asked to describe and/or draw the teacher's image on both sides of the paper. Respondents' personal information was not collected because the tool was not designed to correlate the results of the study with the respondents' gender, place of living, race, nationality or other personality features. 
Although the question was clearly defined for the respondents, the researchers in all the involved countries gained information not only about what a typical teacher is like, but also about what him or her should be like. Thus, we also learnt what society expects from teachers, what the ideal of this profession is.

A person's view on another person is researched in teacher's image analysis, then the researcher interprets this information from his/her own point of view. Consequently, understanding and explaining a teacher's image is a complex process taking place from different perspectives and in different contexts. We all should agree with Gasparini and Vick (2006) when they say that in order to understand the visual image one needs the same literacy as for reading a written text. Therefore, several scientific publications on the study of visual sources (Davey, 1999; Gasparini \& Vick, 2006; Marshall, 2007; Rousmaniere, 2001) and the social aspects of teaching were used.

As body occupies a significant place in a person's visual image, we also used Body Image: A Handbook of Theory, Research, and Clinical Practice, edited by Cash and Pruzinsky (2002). This book compiles concepts about human body from the psychological, physiological, philosophical, social cultural and medical points of view. We also used the very interesting study on the body in postmodern pedagogy carried out by Shapiro (1999), Pedagogy and the Politics of the Body: A Critical Praxis.

However, as Marshall (2007) wrote, all the visual impressions are filtered through experience and culture; no perception is direct and context-free. Therefore, we used May's (2001) approach when speaking about studies in social sciences he describes the political, economic, social and cultural context as well as the ethnomethodological perspective from which the phenomenon is looked upon in the context of collective consciousness. As the age group of the respondents was precisely defined, the description of older teenagers provided by Rutka (2012) as well as the study on the body's image in the view of 12-17 years old youngsters performed by Levine and Smolak (2002) were used.

The results of the study performed in the academic year 20112012 will be used in this article, especially to analyse the situation in Latvia where the study was performed Baiba Kalı̧, author of this article. Understanding that the number of respondents from each country was rather small, we focused on the common traits of teacher's image and paid less attention to the national differences which could have an accidental character. 


\section{Findings. Description of teacher's visual image}

\section{Gender}

Most of the respondents see a woman as a typical teacher. Only respondents in England, Greece and Mexico indicate a male teacher as typical, although students from Mexico often represent a woman in their drawings. In Latvia, 59\% indicated a woman as a typical teacher, which fully matches the statistics of the profession: 18130 teachers work in general comprehensive schools in Latvia, 16303 or $89.9 \%$ out of them are women (Central Statistics Bureau..., 2011). Thus we are able to speak about the feminization of teaching in Latvia as in other countries. This fact, as mentioned in several studies (i.e. Darling-Hammond et al., 1995) diminishes the prestige of teacher's profession.

Still a crucial question is "How do students themselves assess the feminization of teaching? In order to answer this question it is important to find out what features are associated with gender. Negative opinion about male teachers is expressed by students from England -teachers are described with words such as "unpleasant", "sullen" and "shut up!". Also, the answers given by Latvian respondents revealed that a male teacher is considered to be too strict. Female teachers, in their turn, are associated with smile, gentleness and care (Illustrations 2 and 3). However, they are also criticized: students from Slovenia write that "male teachers are usually fun and relaxed; female teachers usually are more serious, small-minded and nagging" (Skubic Ermenc, 2012, p. 57). Male teachers who love humour are mentioned several times in the respondents' answers and this, in its turn, favors male teachers.

It should be admitted that students have noticed both negative and positive features about both genders, and none of genders is acknowledged as ideal for teacher's work. Thus it is possible that the agitation about the feminization of teaching is quite unnecessary.

\section{Age}

To determine teacher's age is not an easy task for fifteen-year old youngsters -from their perspective, someone aged 30 is already quite an elderly person. A student in Latvia writes: "already 30 something". Respondents mention a wide age range for a typical teacher, from 20 to 60. Latvian texts and drawings revealed that teachers are middleaged, which corresponds to the statistical indicators: the majority of teachers in Latvia are 35 to 59 (Central Statistics Bureau..., 2011), that is, middle-aged.

It is no surprising that students prefer young teachers. This leads us to another important question: which features of the teacher are associated with youth, and which with older age? 
Older teachers are criticized for their inability to master modern teaching/learning methods and new technologies, and difficulties to communicate with the younger generation due to different ways of thinking. An older teacher is also described as an exhausted person. Sometimes a teacher's rudeness, aggression, authoritarianism and irritability are connected precisely with the fact that he or she is old (Rodríguez et al., 2012). However, it is possible that unpleasant behaviour makes the person look older.

Students want an energetic, attractive, active teacher and these features are associated with youth. Unfortunately, this desire of the young generation at least in the nearest years in Europe would hardly come true because, as the Report of the European Commission shows, the average number of teachers under 30 in 2010 in EU countries was only 20\% (European Commission, 2012).

Nevertheless, we cannot be absolutely sure and declare that students expect only young teachers at school. Students in Latvia think, "Age in most cases is of no importance but preferably 25-70 because if the teacher is too young then the teacher is not very good because she is too submissive, but if she is old then she is too strict".

\section{Appearance}

Opinions about teacher's image are best revealed in students' drawings. They mainly show the teacher as a slender, proportionally built figure. It is striking that female teachers are drawn without breasts. For instance, students from Serbia, Bulgaria, Turkey, Mexico, Pakistan and Latvia drew young women with absolutely straight body shape (illustration 4). This makes us think that teaching is separated from sexuality by students. Reay (2001) considers this as the stereotype that sexuality and femininity are not compatible with wisdom (p. 157), considered the professional feature of educators.

Some written answers mention that female teachers are "plump" and "pudgy". Students in Slovenia have admitted that teachers are fat (Skubic Ermenc, 2012, p. 58). This, in a 15-yearold definitely is not a compliment because at this age the esthetical standard is for a slim woman (Levine \& Smolak, 2002, p. 74).

Teacher's hair is described in different ways, from short to long hair, from straight to curly hair. Only responses in Greece indicate convincingly that female teachers have long hair (20.7\%) and male teachers have beards (19.2\%) (Calogiannakis et al., 2012, p. 78), 
which actually are clearly explicit gender stereotypes. The common idea is that the teacher's hair is neat and clear, set-twisted in a knot or arranged in a "pony tail". This hairdo is neither complicated nor time-consuming. Students from Latvia write that hair is dyed: "A typical teacher who has worked at school for more than 10 years dyes her hair." It is very possible that this is an indication to teachers' grey hair and students' behavior could be blamed for that.

The choice of the teacher's clothing is determined both by the cultural traditions of the country and his or her age and particular features. The description of clothing in respondents' answers can be divided in three groups: classic, conservative clothing; sport, comfortable wear, everyday clothing and national costume.

Students in Latvia, England and Mexico described teachers in classic clothing more often. A male teacher in Latvia wears a suit or trousers and a shirt, and a tie is one of the most characteristic accessories (illustration 1); female teachers wear matching suits (skirt or trousers and a jacket), skirt, blouses or a jumper, dresses are not much mentioned (illustration 4). Students in Latvia consider that teachers' clothing does not always reflect the latest fashion trends; some have written that clothing is old-fashioned or teachers wear the same clothes all the time. The most frequently mentioned colours are black, gray and white. Clothing differs on holidays when lighter tones come in, clothes are more festive, and teachers wear more jewelry.

Respondents in Serbia, Slovenia, Greece and Bulgaria, in their turn, indicate that a typical teacher wears jeans, T-shirts and pullovers. It is possible to explain it with different opinions about the age of a typical teacher: Slovenian respondents have mentioned that only older female teachers wear classic, every-day and old-fashioned clothes (Skubic Ermenc, 2012, p. 57), in Mexico, older teachers are associated with elegant clothes (Rodríguez et al., 2012, p. 166).

When describing teacher's clothes in general, respondents of all countries have mentioned attributes such as "normal", "politely", "adequately", "according to the etiquette", "clean", "neat", "matterof-fact". Thus the answers predominantly indicate a positive assessment of teachers' clothes.

National traditions in clothing are described in the case of Pakistan. This description reflects the demands set for teacher to observe the norms accepted in society: "A female teacher covers her head, should be a good, practicing Muslim, and a role-model for her pupils through her modest Islamic code of dress" (Gul Khatak, 2012a, p. 151). Strict demands for the "ideal" teacher are set also in other countries regardless the completely different cultural context. One Latvian student writes that "a teacher [...] is one of those who forms the opinion of what an educated adult person 
should look like." Latvian students also indicate that it is not acceptable for female teachers to dress in a young style, as teenagers -the teacher "should know the limits, no need for mini, décolleté". Serbian and Slovenian students think similarly-female teachers should not wear too short skirt and high-heeled shoes, the teacher should not dress provocatively. Students from Turkey write that the teacher should observe the same principles as the students: "[...] if having long fingernails is against school rules, then a teacher should have short nails, too. Or if girls are asked to keep their hair in a pony-tail in school, then the teacher needs to do it herself too" (Lozano \& Kizilaslan, 2012, p. 135).

It is not difficult to notice that girls have expressed their opinion for clothing regarding female teachers. This may be a confirmation to the stereotype that women devote more attention to clothes than men.

The desire to keep distance in the case of outer appearance, probably, proves the students' willingness to have certain distance also in mutual relations: the teacher should stand head and shoulders above- students expect a role model. This fully coincides with the idea expressed by Rose (1999) that a teacher rises above children as a moral example. And it turns out that students like it and they also expect this from teacher.

\section{Glasses, a pointer and a briefcase}

Glasses are the most frequently mentioned of teacher's accessories. They are mentioned or drawn by the respondents from almost all countries in the study (illustrations 1, 2, 3). Students in Latvia write, "Imagining a teacher I immediately think about a woman wearing glasses and a suit", "teachers usually have glasses. Well, actually not all teachers in our school have glasses but I imagine a typical teacher like that"; "A typical teacher has glasses; he usually puts them on when he is reading something and throws them on the table when he is angry with the class." Students in Serbia and Slovenia have marked that a typical teacher wears glasses on the tip of his nose and looks at students over them (Spasenović, 2012, p. 42; Skubic Ermenc, 2012, p. 58).

Glasses in traditional cultures are a strong symbol that indicates both the teacher's dutiful and thankless work correcting students' copybooks thus damaging his or her eye-sight and the belonging to the circles of intellectual readers. Only English respondents pointed out that glasses can also become a symbol 
of status. Students mentioned glasses from Gucci, Prada, D\&G, which can serve as a confirmation of both teacher's prosperity and the students' desire for teachers to wear accessories from well-known brands (Gul Khattak, 2012, p. 17).

Students from England, Serbia, Greece and Latvia have mentioned a briefcase as a teacher's typical accessory. According to the explanations a bag is necessary to carry students' works and the teaching materials, or "constantly 'dragging' some notebooks and papers" (Spasenović, 2012, p. 42).

Although respondents have mentioned that teachers use modern technologies, they are still depicted with a pointer in his or her hand (illustration 2). This is a confirmation to how strong stereotypes preserved in the public sphere are. If we enter the word "teacher" in Google search we get a number of pictures showing a person with a pointer in his or her hand.

We can support the idea expressed by Mitchell and Weber (1998) that glasses, a pointer and a briefcase support teacher's ability to control things and they are symbols of their power and identity (p. 151). Students have not judged these accessories, they have simply admitted that these are attributes used by teachers.

\section{Voice}

Teacher's voice has received the richest choice of attributes. It has received both positive and negative epithets in the countries of the study. It can be "optimistic", "enthusiastic", "soft", "pleasant", "loving", "kind", "clear and articulated", "respectful", "low", "deep", "energetic", "authoritative", "nervous", "monotonous", "slow", "categorical and dominant", "melancholic", "endless", "selfassured", "self-righteous", "strongly threatening", "demanding", "mannered", "precise and piercing", "boring", "threatening and loud". It seems that these descriptions of the voice shortly and precisely characterize also teacher's personality. For instance, $57 \%$ of Mexican respondents, and $48.5 \%$ of Greek respondents have described teacher's voice as friendly (Calogiannakis et al., 2012, p. 78; Rodríguez et al., 2012, p. 167).

Students in England, Slovenia, Mexico and Latvia have described teacher's voice as loud. This is perceived with understanding that teachers have to speak louder than 30 or even 40 students. Respondents in Slovenia, Turkey and Latvia think that teachers speak a literary correct language. Students from Latvia write that teachers' speech does not include jargon words, simply colloquial words: "Don't use rude words in front of the others." Latvian students think that teachers' language is rich; they use many foreign words and that is good: "Teachers should speak in a way that students think that they are talking with a clever person."

Sometimes teachers speak too much. Both students in Bulgaria and Latvia expressed this opinion: 
"Speaking is inborn for them since the childhood." Students from Latvia write that teachers speak in a balanced way, calmly, strictly, definitely, "in full, meaningful sentences; they always express their opinion, a bit in a threatening manner."

Respondents have indicated that teachers use their voice to discipline students and do it through shouting. Latvian students have observed that when a teacher is angry his or her voice becomes louder, the tone becomes high-pitched, threatening. Serbian students write that teacher "yells when gets annoyed" (Spasenović, 2012, p. 42). A shouting teacher is mentioned also in the answers given by students in Bulgaria, South Africa and Turkey.

The detailed and emotional descriptions of a teacher's voice shows that this is one of the most important professional tools, even another instrument of power (Manke, 1997, p. 123). Teachers can use it to earn students' trust and love, as well as to create fear and reprehend them.

\section{Non-verbal communication}

Psychologists believe that emotionally saturated information is transferred predominantly in a non-verbal way-with the help of distance, pose, eye contact, mimicry, movements and gestures (Omārova, 2003, p. 54). Thus, it is not surprising that teachers' gestures and mimicry have received the greatest number of respondents' extreme assessments, both negative and positive.

Some respondents believe that a teacher's facial expression typically is pleasant and smiling. Students in Serbia and Slovenia as well as in Bulgaria see teacher like that. The majority of respondents in these countries write that the teacher's facial expression is calm, patient, friendly, and attractive. They often smile (Duridanov \& Popvasileva, 2012, p. 98). In Greece, 46.4\% of respondents admit that the teacher is smiling and $59.2 \%$ that he or she loves humour (Calogiannakis et al., 2012, p. 79). In Latvia only $6 \%$ of respondents have indicated that the teacher is smiling and one student has even considered it a negative feature, "... and that mysteriously happy smile when someone has to be given an unsatisfactory mark."

Latvian students in their drawings have mainly depicted drawn eyebrows, an angry facial expression, or a pose in which the teacher expresses dissatisfaction and aggression with all of his or her body. hands in the trouser pockets, behind the back, crossed on the chest each has been drawn for once. Students in Bulgaria, 
Serbia and Mexico also indicate that teachers sometimes are angry, uncontrolled and nervous. Depending on their mood or personal problems their facial expression can be angry, worried, mean, scornful, or ironic. A student in Slovenia writes that "they do not show emotions unless they become angry- then they show their emotions loudly and clearly with a stern look over the glasses" (Skubic Ermenc, 2012, p. 59). Students have mentioned also that the teacher's mood can change all over the day: "When they come to school happy, their behaviour is kind to us, but when they become angry about something, we get punished for anything" (Canales Rodríguez et al., 2012, p. 168).

Gesturing has been assessed positively and negatively depending on cultural traditions. For instance, Latvian students mention that the teacher makes gestures when he or she is angry, while Greek students like it when teachers gesticulate.
According to students, the teacher is either at school, or "empty", without context. There are no drawings where the teacher is performing an action that is not connected with teaching. A typical teacher is in the classroom, either sitting at the table, in front of the class, or standing by the blackboard (illustration 3). This way the teacher is well seen and he or she can see students. The few drawings in which the teacher is depicted together with students have a common trait: students are proportionally much smaller than teachers. That, certainly, points at the huge authority teachers enjoy and achieve through different means. A typical drawing made by a student from Latvia shows a teacher evidently "teaching", but the classroom is...empty (illustration 3). It reminds of the idea expressed by Shapiro (1999) about invisible people ("nobodies") who point at their marginalized place in the social hierarchy of the society. 


\section{Illustration 1}
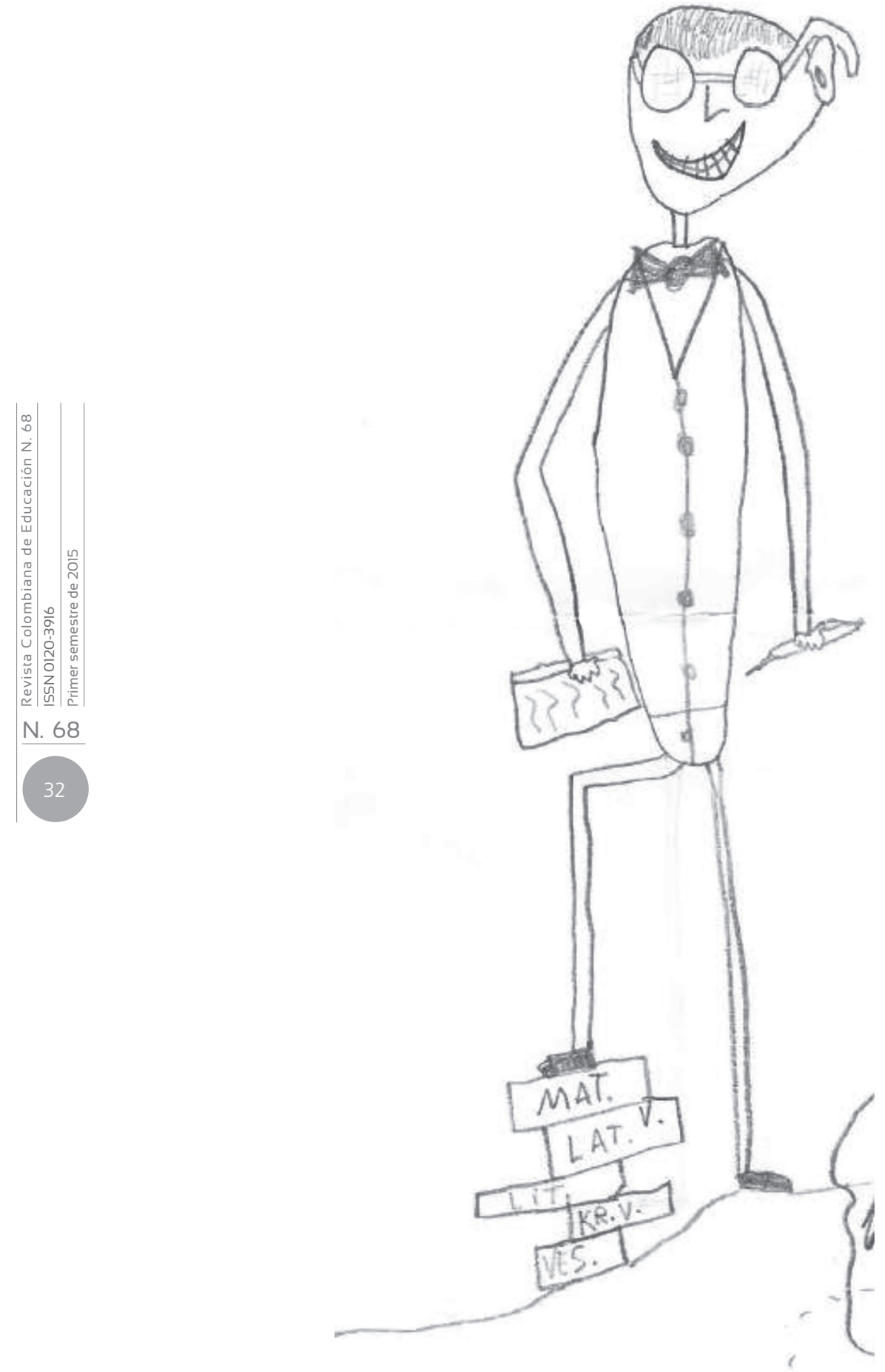
Illustration 2
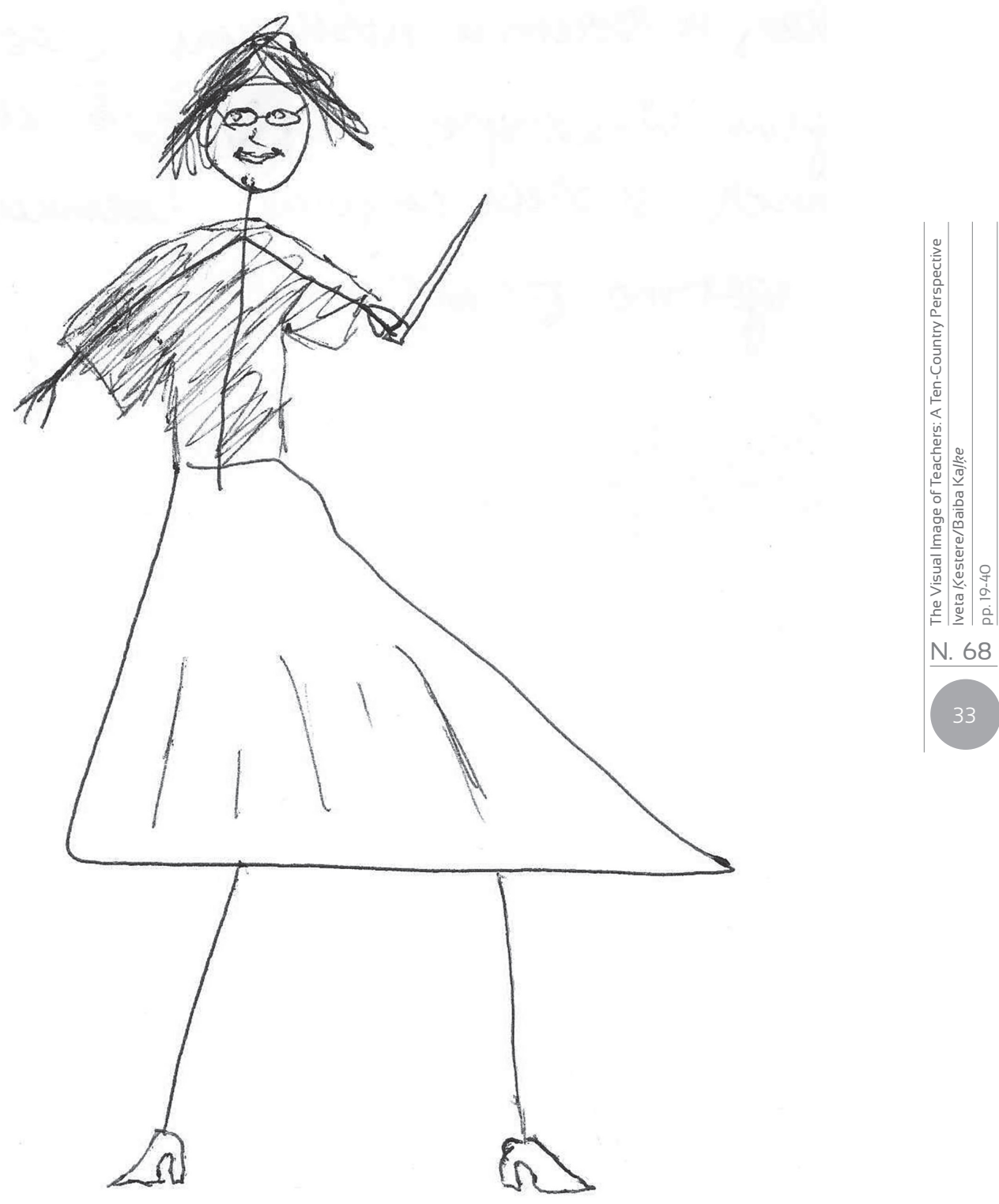
Illustration 3

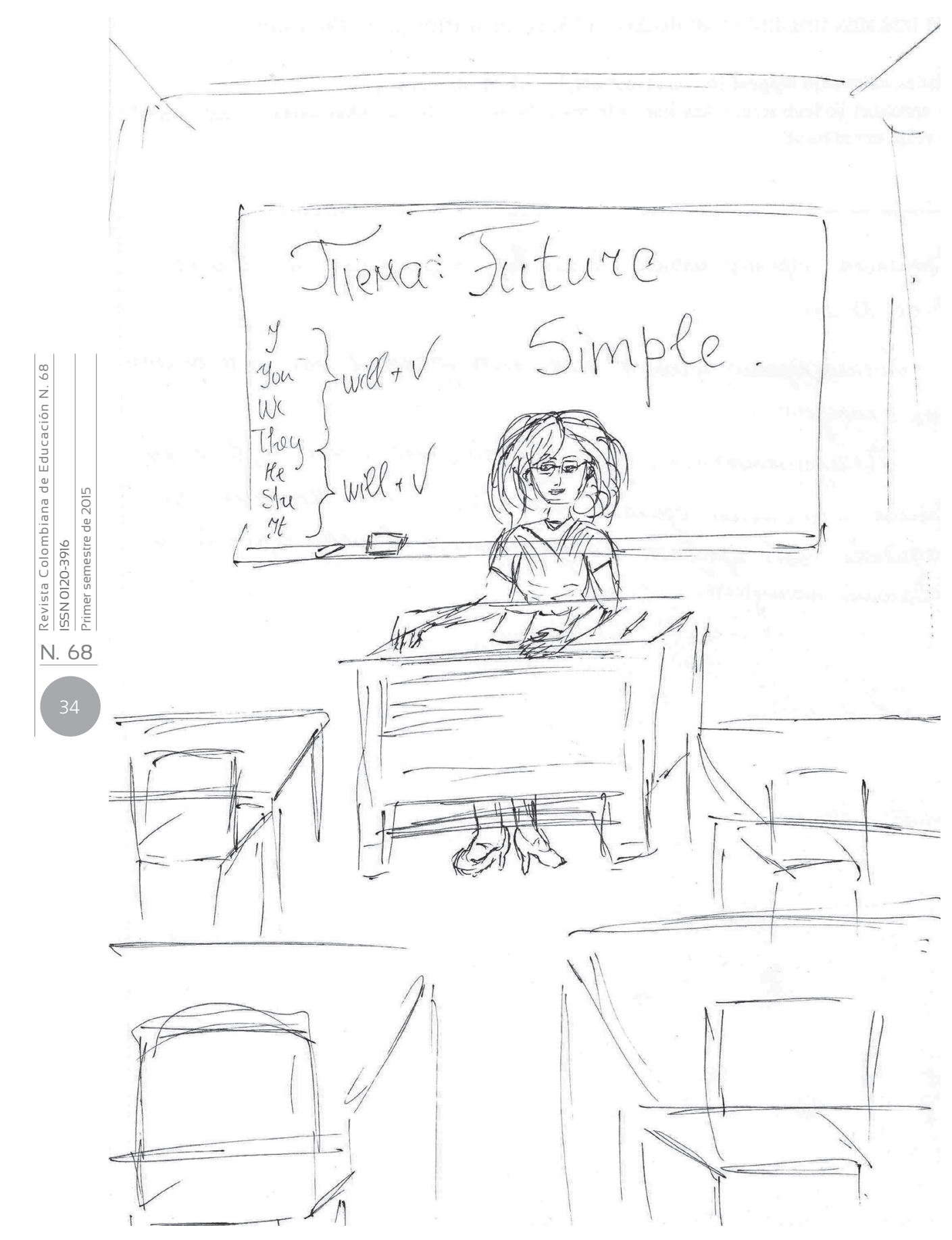


Illustration 4
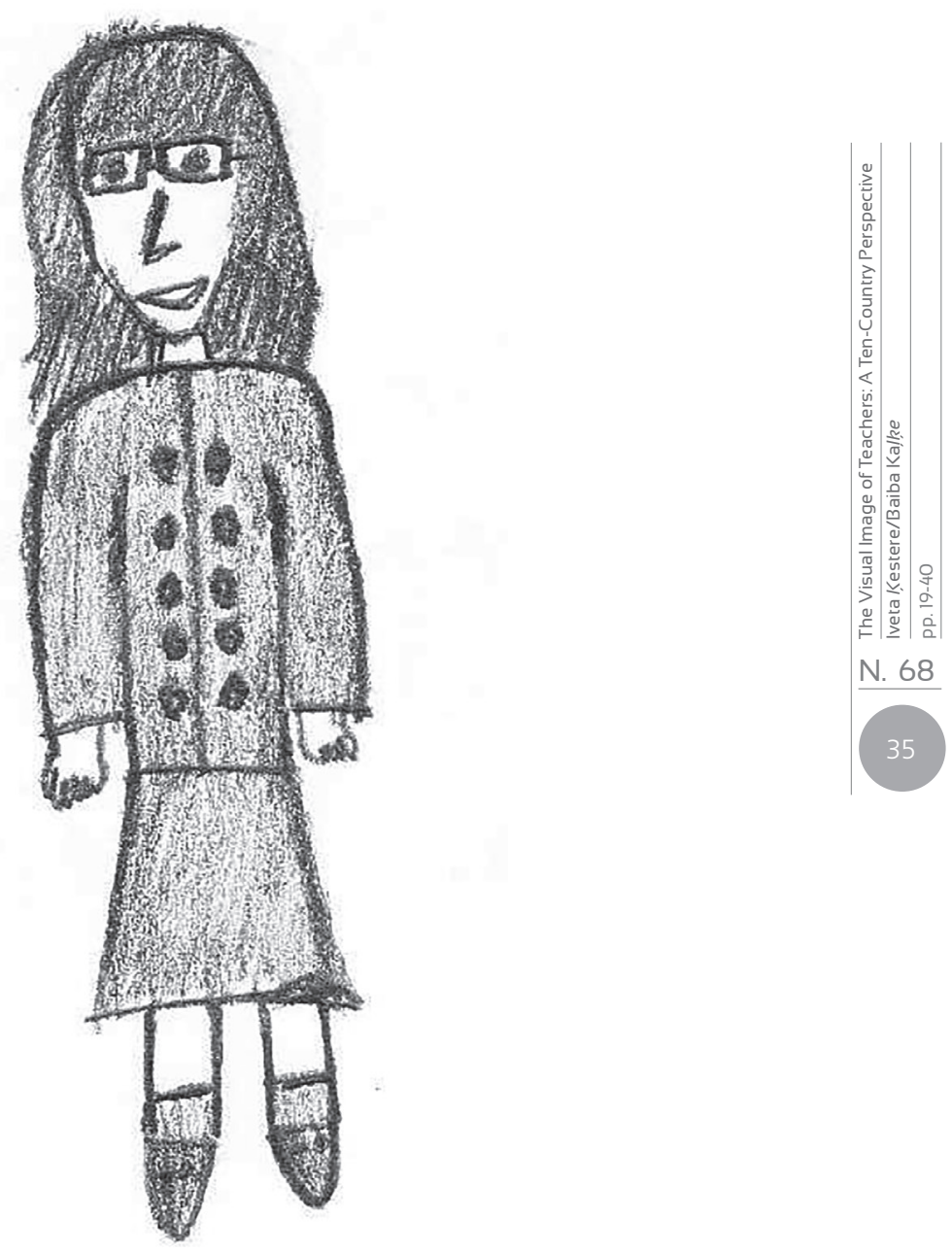


\section{Conclusions and discussion}

Our study proves how important teacher is in the life of students. The evidence of this is the emotional descriptions of the "extremely good" and the "extremely bad" teacher as well as the desire to see teachers as role models. These expectations of students and society for teachers to be a moral example place an additional load on teacher's shoulders. A teacher, just being a real, alive person, certainly cannot be flawlessly ideal. As a result, society sometimes gets disappointed about teachers, and teachers themselves become disappointed about their profession. As very conscientious people usually become teachers, then the failure to fulfill society's expectations creates discomfort.

However, if we abstract ourselves from the exaggerated expectations about teachers as an ideal, then we can conclude that students have expressed much good about the image of real teachers. Different teachers are welcomed and expected at school -positive features are revealed both in male and female teachers, in younger and older teachers. There are many smiling and kind teachers who do not use their voice for shouting, but for clear and loud talking in the classroom.

The inconspicuous and even plain outer appearance of teachers is accepted, arguing that teacher's appearance must not deviate students' attention from learning. If we look into the history, it can be seen that teaching traditionally has been closely connected with popularizing the religious values, among which modesty outstands as one of the most important moral features. Modesty as a value is still topical in many societies and this leads to a paradoxical answer: lack of financial means and time often does not allow teachers to look vivid, but actually society is not expecting it from teachers because a modest but neatly looking teacher is a beneficial example for youngsters. This proves that property is not the most important thing in life, that intellectual achievements are more important. And such an idea, definitely, is attractive to part of society.

The teacher's place in the classroom has remained unchanged for hundreds of years. He or she stands in front of students, where he or she can be seen by everyone and from where he or she can see all of them. Our study confirms the development in a positive direction. Teachers have become more dynamic; they are no longer sitting, but communicate through body language. The description of teacher's clothes as "comfortable and sportive" also 
indicates the activity. Thus, teachers tend to choose comfortable clothes that allow them to move easily. The teacher in the description given by a Latvian student reminds a bit of a dexterous hunter: "The teacher is characterized by fast gait, good eyesight and hearing."

We, as authors, believe that the respondents' ideas about the teacher as an exceedingly significant character in the life of young people can become the foundation for increasing the prestige of teaching.

\section{References}

Ayers, W. (2001). A Teacher ain't nothin' but a hero: Teachers and teaching in film. In: P. Bolotin Joseph \& G. E. Burnaford, eds. Images of Schoolteachers in America. Mahwah, N. J., London: Lawrence Erlbaum Associates, pp. 201-209.

Calogiannakis, E., Karras, K. G. \& Palios, Z. K. (2012). Teacher Visual Image: the Case of Greece. In: Kestere, I., Wolhuter, C. \& Lozano, R., eds. The Visual Image of the Teacher: International Comparative Perspectives. Riga: RaKa, pp. 68-85.

Cash, T. F. \& Pruzinsky T., eds. (2002). Body Image: A Handbook of Theory, Research, and Clinical Practice. New York: Guilford Press.

Centrālās statistikas pārvaldes datu bāze. Tsg11-11. 15 gadu un vecāki Latvijas nodarbinātie iedzìvotāji pēc profesijas/amata pamatdarbā, dzimuma un pa vecuma grupām 2011.gada 1.martā. [Data basis of the Central Statistical Bureau. Tsg11-11. Employed population of Latvia aged 15 and older according to profession/post in the basic employment place, gender and age groups. March 1, 2011]. Retrieved from http://www.csb. gov.lv/dati/statistikas-datubazes-28270.html (2012.03.12)

Chambers, D. W. (1983). Stereotyped images of the scientist: The draw-a-scientist-test. Science Education, 67, 255-265.

Cohen, L., Manion, L. \& Morrison, K. (2007). Research Methods in Education. London and New York: Routledge.

Darling-Hammond, L., Wise, A. E. \& Klein, S. P. (1995). A License to Teach: Building a Profession for 21st-Century Schools. Boulder, CO: Westview Press.

Davey, N. (1999). The hermeneutics of seeing. In: Heywood, I. \& Sandywell, B. (eds). Interpreting Visual Culture: Explorations in the Hermeneutics of the Visual. London: Routledge.

Depaepe, M. (2000). Demythologizing the educational past. The endless task of history of education. In: R. Lowe, ed. History of Education: Major Themes. Vol. I: Debates in the History of Education. London/New York: Routledge, pp. 356-370.

Duridanov, L. \& Popvasileva, T. (2012). Typical Image of the Teacher in Bulgaria: the 
Secrets of Body Language. In: Kestere, I., Wolhuter, C. \& Lozano, R., eds. The Visual Image of the Teacher: International Comparative Perspectives. Riga: RaKa, pp. 86-105.

EC Eurostat. Education Statistics, 2011. Retrieved from http:// epp.eurostat.ec.europa.eu/statistics_explained/index.php/ Education_statistics\#Women.C2.A0in_the_teaching_profession (2012.03.12).

Education at a Glance 2012. OECD indicators. Retrieved from http://www.oecd.org/edu/EAG\%202012_e-book_EN_200912.pdf (2014. 18.06.).

Eiropas Komisija. Skolotāju novecošana - izaicinājums ES izglītības nozarei. Pazinojums presei 2012.gada 11.septembrī [European Commission. Teachers' aging- a challenge for education in EU. Press release. September 11, 2012]. Retrieved from http://europa.eu/rapid/press-release_IP-12-950_lv.htm (2012.04.12).

Enzelberger, S. (2001). Sozialgeschichte des Lehrerberufs. Gesellschaftliche Stellung von Lehrerinnen und Lehrer von den Anfäng bis zur Gegenwart. Wainheim, München: Juvena.

Fischer, J. \& Kiefer, A. (2001). Constructing and Discovering Images of Your Teaching. In: P. Bolotin Joseph \& G. E. Burnaford, eds. Images of Schoolteachers in America. Mahwah, N.J., London: Lawrence Erlbaum Associates, pp. 93-114.

Gasparini, F. \& Vick, M. (2006). Picturing the History of Teacher Education: Photographs and Methodology. History of Educational Review, 35 (2), 16-31.

Gul Khattak, S. (2012a). The Visual Image of Pakistani Teachers: Myths and Realities. In: Kestere, I., Wolhuter, C. \& Lozano, R., eds. The Visual Image of the Teacher: International Comparative Perspectives. Riga: RaKa, pp. 144-157.

Gul Khattak, S. (2012b). The Visual Image of Teacher: an English Perspective. In: Kestere, I., Wolhuter, C. \& Lozano, R., eds. The Visual Image of the Teacher: International Comparative Perspectives. Riga: RaKa, pp. 10-23.

Hobson, D. (2001). Shifting images across the generations: Conversations with beginning, current, and retired teachers. In: Joseph, P. B. \& Burnaford, G. E. (eds.). Images of Schoolteachers in America. Lawerence Erlbaum Associates Publishers, pp. 51-73.

Joseph P. B. \& Burnaford G. E., eds. (2001). Images of Schoolteachers in America. Lawerence Erlbaum Associates Publishers. 
Kantor, K., Kantor, N. L., Kantor, J., Eaton, M. \& Kantor, B. (2001). 'I will not expose the ignorance of the faculty': The Simpsons as school satire. In: Joseph, P. B. \& Burnaford, G. E. (eds.). Images of Schoolteachers in America. Lawrence Erlbaum Associates Publishers, pp. 185-200.

Kestere, I. \& Kalke, B. (2011). Teacher's visual image: the Latvian student perspective. In: N. Popov et al., eds. Comparative Education, Teacher Training, Education Policy, Social Inclusion, History of Education. Volume 9. Sofia: Bureau for Educational Services, pp. 409-417.

Kestere, I., Wolhuter, C. \& Lozano, R., eds, 2012. The Visual Image of the Teacher: International Comparative Perspectives. Riga: RaKa.

Levine, M. P. \& Smolak, L. (2002). Body image development in adolescence. In: Cash T. F., Thomas Pruzinsky T. (eds). Body Image: A Handbook of Theory, Research, and Clinical Practice. New York: Guilford Press, pp. 74-82.

Lozano, R. \& Kizilaslan, I. (2012). Education in Turkey: Sentimentality Meets the Realities of the Teaching Profession. In: Kestere, I., Wolhuter, C. \& Lozano, R., eds. The Visual Image of the Teacher: International Comparative Perspectives. Riga: RaKa, pp. 126-143.

Manke, M. P. (1997). Classroom Power Relations: Understanding
Student-Teacher Interaction. Mahwah, New Jersey London: Lawrence Erlbaum Associates.

Marshall, J. (2007). Image as insight: Visual images in practice-based research. Studies in Art Education, 49 (1), 23-41.

May, T. (2001). Social research: issues, methods and process. Philadelphia: Open University Press, 2001.

Mead, M. (1951). The School in American Culture. Harvard University Press, Cambridge.

Misāne, G., Gurbo, M., Jemeljanova, M. \& Dedze, I. (2007). Pētījums par pedagogu profesijas prestižu un iespējām to paaugstināt dažādu mērksauditoriju skatījumā [The study on the prestige of the pedagogues' profession and possibilities to increase it in the views of different target audiences/ Rīga: SIA Invite konsultācijas]. Riga: Invite Consultations, Ltd.

Mitchell, C. \& Weber, S. (1999). Reinventing ourselves as teachers: Beyond nostalgia. London: Falmer Press.

Nóvoa, A. (2000). Ways of Saying, Ways of Seeing: Public Images of Teachers (19 $9^{\text {th }}-20^{\text {th }}$ Centuries). Paedagogica Historica, 36, (1), pp. 21-41.

Omārova, S. (2003). Cilvēks runā ar cilvēku [Person speaks with a person]. Rīga: KAMENE.

Reay, D. (2001). The paradox of contemporary femininities in education: combining fluidity with fixity. In: Francis, B. \& Skelton, 
Ch. (eds.). Investigating Gender: Contemporary Perspectives in Education. Philadelphia: Open University Press, 2001.

Rodríguez, Canales, E. L., Martínez Rodríguez, R. del C. \& Arenas Basurto, J. G. (2012). Teacher Image in Different Educational Contexts: the Case of Mexico. In: Kestere, I., Wolhuter, C. \& Lozano, R., eds. The Visual Image of the Teacher: International Comparative Perspectives. Riga: RaKa, pp. 158-173.

Rose, N. (1999). Powers of Freedom: Reframing Political Thought. Cambridge, England: Cambridge University Press.

Rousmaniere, K. (2001). Questioning the visual in the history of education. History of Education, 30 (2), 109-116.

Rutka, L. (2012). Pedagoga psiho-logiskā kompetence [Psychological competence of the pedagogue]. Rīga: RaKa.

Shapiro, S.B. (1999). Pedagogy and the Politics of the Body: A Critical Praxis. New York: Garland.

Skubic Ermenc, K. (2012). The Twofold Image of a Typical Teacher in Slovenia. In: Kestere, I., Wolhuter, C. \& Lozano, R., eds. The Visual Image of the Teacher: International Comparative Perspectives. Riga: RaKa, pp. 50-67.

Smith, A. (2009). Enhance the image of the special education teacher. Delta Kappa Gamma Bulletin, 75 (2), 27-29.

Spasenović, V. (2012). The Visual Image of the Teacher: a Serbian Perspective. In: Kestere, I., Wolhuter, C. \& Lozano, R., eds. The Visual Image of the Teacher: International Comparative Perspectives. Riga: RaKa, pp. 34-49.

Utley, J. \& Showalter, B. (2007). Preservice elementary teachers' visual images of themselves as mathematics teachers. Focus on Learning Problems in Mathematics, 29 (3), 1-14.

Vick, M. (2000). What does a teacher look like? Paedagogica Historica, 36 (1), pp. 247-263.

Weber, S. \& Mitchell, C. (1998). 'That's Funny, You Don't Look Like a Teacher': Interrogating Images and Identity in Popular Culture. London, Washington, D. C.: The Falmer Press.

Wolhuter, C., Steyn, H., Taloe, M. J. \& Geyer, W. (2012). The Dual Image of the South African Teacher. In: Kestere, I., Wolhuter, C. \& Lozano, R., eds. The Visual Image of the Teacher: International Comparative Perspectives. Riga: RaKa, pp. 24-33. 